\title{
Fiscal Policy to Create Connectivity for National Logistic System and its Economic Impact
}

\author{
Rita Helbra Tenrini", Sofia Arie Damayanty* \\ ${ }^{\#}$ Researcher at Fiscal Policy Agency, Ministry of Finance of Republic of Indonesia, \\ Center of State Budget Policy, R.M. Notohamiprodjo Bld, 5th Flr, Dr. Wahidin No. 1 Jakarta, 10710, Indonesia \\ E-mail: rita.helbra@gmail.com \\ *Researcher at Fiscal Policy Agency, Ministry of Finance of Republic of Indonesia, \\ Center of Fiscal Risk Management,R.M. Notohamiprodjo Bld, Dr. Wahidin No. 1 Jakarta, 10710, Indonesia \\ E-mail:momizzan@gmail.com
}

\begin{abstract}
Indonesia's Balance of Payments for transportation services turned to deficit for past few years. The biggest share comes from deficit on transportation services for freight. This is one reason why the cost for transportation services in Indonesia is very high and at the end it will reduce the national competitiveness. Blueprint for The development of National Logistics System already regulated in Presidential Regulation No. 26 year 2012. The implementation of National Logistics System can create national competitiveness and support the implementation of the Masterplan for Acceleration and Expansion of Indonesian's Economic Development (abbreviated MP3EI). National Logistics system is expected to be operationalized by the logistics service providers, and supported by the availability of adequate logistics infrastructure and reliable. Service providers for all across Indonesia will be needed in order to create connectivity for National Logistic System. Transportation service providers that came from domestic, can reduce the cost of transportation, and it will create national competitiveness for domestic production. The purpose of this study is to identify the appropriate fiscal policy to domestic service providers and to identify the economic impact of the increasing on services from domestic service provider. The methodology used in this research is analysis using Social Accounting Matrix (SAM) that can give an overview the impact of increasing production in one sector to factors of production, institution, and other sector. Economic impact analysis that came from SAM indicates that the increasing production in transportation services sector have an overall positive impact to factor of production, institution and other sector. The results of this research is expected to help policy makers in the field of fiscal policy in designing appropriate policies for domestic transportation service provider and at the end to help reduce the Balance of Payments deficit for transportation services.
\end{abstract}

Keywords — Transportation Services, National Logistics System, Fiscal Policy, Social Accounting Matrix

\section{INTRODUCTION}

Indonesia experienced significant economic growth in recent years. In 2009, one year after the subprime mortgage crisis in the United States, Indonesia's economy could grow $4.2 \%$ while other countries (except China and India) experienced negative growth. In 2013 Indonesia's economy is still able to grow above $5.7 \%$, despite the impact of the European debt crisis in 2010 still affect the world economy.

However, impact of economic crisis on the export destination countries had influenced global trading activities. At the end of 2011, Indonesia's experiencing current account deficit for the first time since the last 50 years. The current account deficit is due to the declining of trade balance surplus, caused by the increasing of import sand decreasing of exports. Condition of Indonesian Balance of Payment also influenced by market perception on tapering of quantitative easing in USA which affected the volatility of exchange rate. This situation made the government announced the Policy for Stabilization and Economic Growth on August 2013 as the effort to maintain the macro economics stability.

Indonesia's current account deficit also contributed from the service account which is always deficit during the last 10 years. As shown in figure 1, the service account has little positive contribution from travel sector. The main contributor of service account deficit was from transportation sector, particularly from freight. This indicates that Indonesia is using foreign freight services more than give service for other countries. 


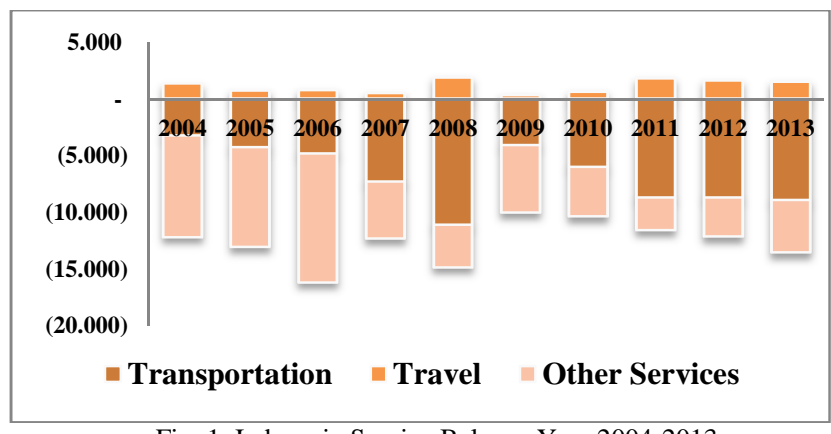

Fig. 1. Indonesia Service Balance Year 2004-2013

Source: Central Bank of Indonesia

Moreover because of the dependence on foreign freight service, there is a strong relationship between transportation services account deficit with the volume of international trade in Indonesia as shown in figure 2. Under this relationship, the transportation services cannot support the improvement of current account deficit, because if economy has a greater volume of international trade, then it will cause to greater imports of transportation services.

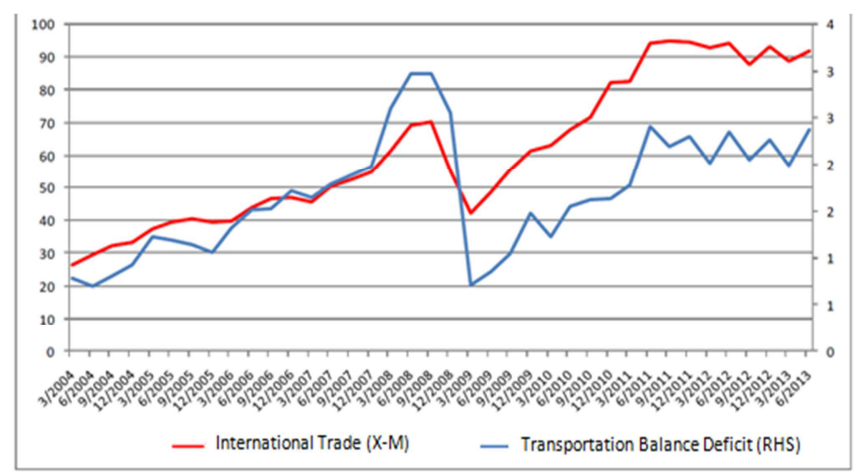

Fig. 2 International Trade and Transportation Balance

Source: Central Bank of Indonesia, Ministry of Finance

Reference [1] mention that infrastructure specifically for transportation is always become main issue in Indonesia. KADIN (Indonesia Trading and Industrial Chamber) stated that logistic cost in Indonesia is about $24 \%$ of GDP or worth Rp1.820 trillion per year, which $60 \%$ is for transportation cost. ASEAN countries has an average logistic cost about $20-21 \%$, South Korea 16,3\%, Japan 12\%, and even United States of America with larger area than Indonesia has a relatively lower logistic cost to GDP ratio, which is $10 \%$. Logistic cost to GDP ratio indicates the logistic efficiency of a country.

Therefore to overcome the transportation problem particularly in logistic, government of Indonesia designed National Logistic System (abbreviated Sislognas) to create logistic system that locally integrated and globally connected for national competitiveness and social welfare. Sislognas is part of the Masterplan for Acceleration and Expansion of Indonesian's Economic Development (abbreviated MP3EI) which will provide direction for Indonesian economic development until 2025.

Although the quality of infrastructure for transportation still need to be improved, government effort already showed positive results, that can be seen from the six points increase of Indonesia's rank for Logistic Performance Index in 2014, from the previous rank 59 as in[2]. Continous and massive development in transportation sector is needed to increase the productivity and opportunity of doing business in Indonesia.

This study aims to identify the economy impact of the increasing ouputon transportation services sector from domestic service provider, and recommend the appropriate fiscal policy to increase the productivity of domestic service provider in order to improve the contribution of transportation services to economy and social welfare.

\section{LITERATURE REVIEW}

\section{A. Balance of Payment and Current Account}

Balance of payments (BOP) is a statistical statementthat systematically summarizes, for a specific timeperiod, the economic transactions of an economy withthe rest of the world as in [3]. There are three catagories of transaction in BOP, which are current account (records goods, services, income and current transfers), capital account (records phisycal assets), and financial account (records assets pertaining to international monetary flows of, for example, business or portfolio investments).

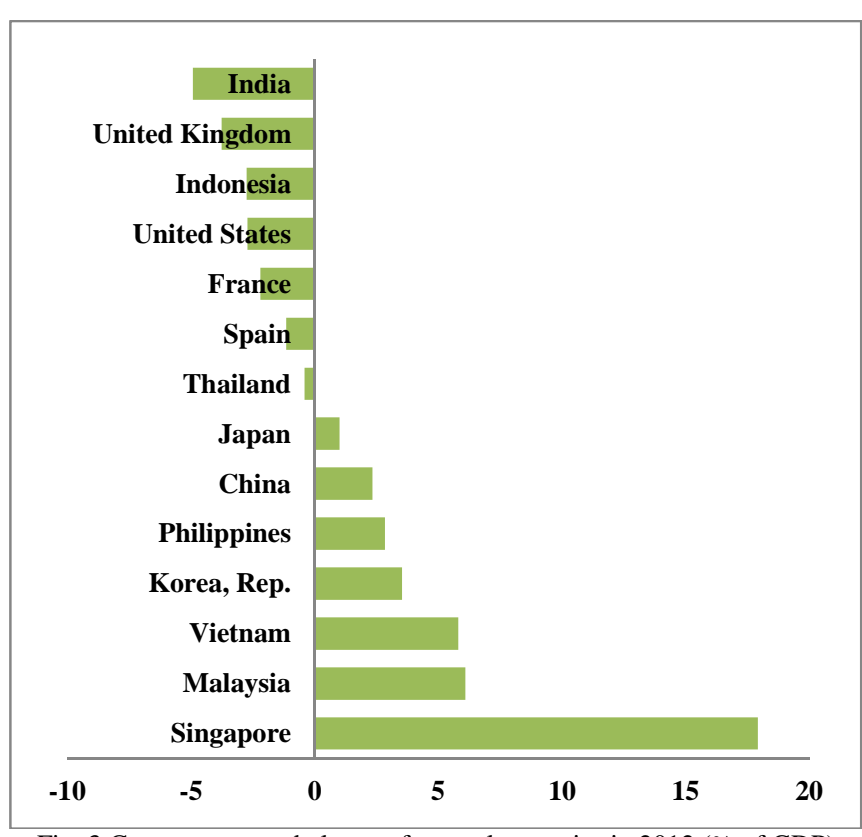

Fig. 3 Current account balance of several countries in 2012 (\% of GDP) Source: http://data.worldbank.org/indicator/BN.CAB.XOKA.GD.ZS

Current account deficit reflects the economy has become a net importer of goods, services and investment incomes.Figure 3 shows that current account balance for year 2012 not only experienced by developing countries, but also for developed countries. This status is not necessarily a bad thing for an economy, especially for an economy in the developing stages or under reform that sometimes has to spend money to make moneyas in [4].Reference [5] mention that that some of the policies that can be done to improve trade performance in order to fix the current account are:

a. Expenditure-reducing policies, designed to control demand and limit spending on imports,

b. Expenditure-switching policies, designed to change the relative prices of exports and imports. This causes 
changes in spending away from imports and towards domestic/export production,

c. Improving the supply-side performance of the economy to boost competitiveness. Economic reform can be done as a long run strategy,

d. Improving macroeconomic stability to make a country more attractive to inward investment that can raise productivity and country's capacity for exporting.

\section{B. Relationship Between Infrastructure and Transportation with Economic Development}

Competitiveness of a country can be boosted by developing qualified infrastructure. Infrastructure development has significant positive contribution to growth in China, as the fastest growing country in the world for last few decades. Therefore it is suggested that design of economic policy that improves the physical infrastructure is necessary for sustainable economic growth in developing countriesas in [6].

Reference [7] mention that economic theory also states that improves transportation systems along with a cluster business, education, research, leisure, and other socio/techno-economic activities can facilitate increased trade and economic growth within a given region. In the case of Korea, government innovative attention to related technology development for comprehensive transportation infrastructure and storage facilities since could enforce national competitivenessas in [8].

Since infrastructure has a significant relationship with trade activities, the elasticity of trade costs with respect to the quality of infrastructure for several Asian countries also had been estimated. The result indicated that a one percent improvement in transport infrastructure decreased the trade cost equivalents for the value traded by $0.03-0.58$ percent in most developing Asian countries assessed during 1988-2003 as in [9].

\section{Indonesia's Transportation and Infrastructure Development}

Indonesia national marine transportation services dominated by foreign companies that undermine the competitiveness of the trade of national commodity.There are three factors that undermine the development of a national transportation services: (a) the lack of regulation sand national policies, (b) poor transportation security, and(c) the poor condition of the sea port, as in [10]. In order to encourage and to induce national companies in maritime industry, Indonesia Government has implemented the cabotage principle $^{1}$ under the Maritime Law No. 17 of 2008. The principle will mainly oblige every vessel and shipping companies to operate under Indonesian law and regulations.

In fact, improvement on regulationis not enough. Although the cabotage principle has been

\footnotetext{
${ }^{1}$ Cabotageprinciple is principle recognize in the maritime law, especially in the shipping. The principle can be defined as that domestic shipping is entirely the right of the domestic state. Domestic state is entitled to forbid and restrict foreign vessel to sail and to conduct business in the area of the state. The cabotage principle will ensure (a) the protection and to safeguard national maritime industries development, (b) the support of national security, defence, and national economic. (c) the prevention of dependency to foreign vessel and foreign companies, (d) working and business opportunities for the local as in[11]
}

establishedsince2008, the balance of services in the field of transport (especially in freight) is still deficit. Therefore, it is also necessary to improve the quality of infrastructure to support the development of national transportation services, especially for seaport as a main gate for local and international trading.

Various studies show that over the next 20 years flow of container in Indonesia will increased dramatically, from 8.8 million TEU in 2009 estimated to be 30 million TEU by 2020, and 48 million TEU in 2030, dry bulk cargo and liquid is expected to increase by 50 percent during the decade and 50 percent again next start 2020 till 2030 as in [12]. Indonesia needs to move quickly to expand and modernize its ports to keep up with market demands. The country's current ports are overstretched and will become bottlenecks to further trade expansion if Indonesia doesn't build better infrastructure.

To achieve the mission of Indonesia become developed countries by 2025 as stated in the Masterplan for Acceleration and Expansion of Indonesian's Economic Development (abbreviated MP3EI), one of the government's strategy is to create a National Logistic System (abbreviated Sislognas). There are six key drivers in national logistic system that should be collaborate to improve the competitiveness and welfare: key commodity, logistic infrastructure, logistic service providers, human resources, information and communication technology, and the harmonized policy and regulationas in [13]. With Sislognas, these key drivers will work integratively to reach Indonesia Economic Vision 2025: realization of independent, progressive, equal, and prosperous society.

\section{METHODOLOGY}

Methodology used in this study to estimate the economy impact of the increasing ouput on transportation services sector from domestic service provider was Social Accounting Matrix multiplier. In this study we used secondary data from Central Agency on Statistics, which is SAM year 2008 matrix 105 x 105 with 24 sectors.

Reference [14] mention that Social Accounting Matrix (SAM) has become used increasingly in the last years as a general equilibrium data system linking, among other accounts, production activities, factors of production and institution (companies dan households). SAM can captures the circular interdependence charasteristic of any economic system among production, the factorial income distibution, the income distribution among institutions and particularly, among different socio-economic household groups.

The effects of exogenous injections on the whole economic system can be indicated by multiplier analysis which requires partitioning the SAM into endogenous and exogenous accounts. Typically the former include (i) production factors; (ii) institutions (companies and households); and, (iii) production activities, while the exogenous accounts consist of (iv) government;(v) capital; and (vi) the rest of the world.

A SAM is a matrix representation of transactions in a socio economic system. It is a comprehensive, exible, and disaggregated framework, which elaborates and articulates the generation of income by activities of production and the distribution and redistribution of income between social and 
institutional group as in [15]

In a SAM framework every agent's expenditure has to equal its receipt (in the form of equality between column and row sum), so that SAM explicitly represents the initial equilibrium, or market clearing conditions in the economy. Every good and service produced by industry is equal to what is demanded. Each factor of production supplied has to be absorbed by industry, and household spending has to be equal to income.

TABLE I

SOCIAL ACCOUNTING MATRIX

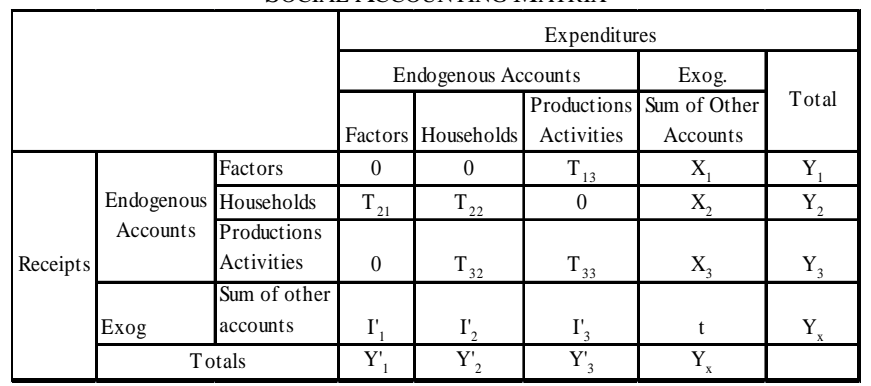

Reference [16] in figure 4shown that T13 which allocates the value added generated by the various production activities into income accruing to the factors of production; T33 is the intermediate input requirements like in the input-output table. T21 shows the factorial income distribution into the household income distribution. T22 captures the income transfers within and among house hold groups; and finally T32 reflects the expenditure pattern of the various institutions for the different commodities (production activities) which they consume.

In this study we are using secondary data from Central Agency on Statistics. SAM year 2008 is the latest version of SAM Indonesia. SAM year 2008 used in this study to calculate economy impact from policy implementation that we proposed in this study.

Multiplier $M_{\mathrm{a}}$ is a tool to estimate the impact of an exogenous shock on income of the endogenous accounts. It will capture the direct and indirect effects from the shock as in [16]

$$
y_{n}=A_{n} y_{n}+x=\left(I-A_{n}\right)^{-1} x=M_{a} x[1]
$$

The matrix of multiplier $M_{\mathrm{a}}$ shows the impact of an external shock on any given sector to economy. The result of matrix multiplier is a comparison of how the economy looks before and after a change in economy policy concerning tax rates of public investment, or an alteration in some other external condition such as the level of export demand. From the viewpoint of understanding the process of economic adjustment to these external shocks, the information provided by these multipliers alone is limited as in [17].

There is three way of analyzing the SAM multipliers, First the process by which the multiplier effects accumulate round-by-round will be examined. Second, a procedure developed by Pyatt and Round as in [18] there are three submultipliers, each of which alone calculates shock effects as they travel through subsections of the total matrix. And third, a variation on this decomposition provided by Stone as in [19].

Decomposition provided by Stone start with making three multiplier matrix. First, matrix $M_{1}$ that contains the own, intragroup or direct effects multipliers. The matrix for $M_{1}$ :

$M_{1}=\left[\begin{array}{ccc}(I-A)^{-1} & 0 & 0 \\ 0 & I & 0 \\ 0 & 0 & (I-H)^{-1}\end{array}\right]$

Second, $M_{2}$ matrix that provides extragroup, indirect or open loop multipliers. The matrix for $M_{2}$ :

$$
M_{2}=\left[\begin{array}{ccc}
I & (I-A)^{-1} C(I-H)^{-1} Y & (I-A)^{-1} C \\
V & I & V(I-A)^{-1} C \\
(I-H)^{-1} Y V & (I-H)^{-1} Y & I
\end{array}\right][3]
$$

Finally, the $M_{3}$ matrix multiplier that provides intergroup, cross or closed loop multipliers. The matrix for $M_{3}$ :

$M_{3}=\left[\begin{array}{ccc}{\left[I-(I-A)^{-1} C(I-H)^{-1} Y V\right]^{-1}} & 0 & 0 \\ 0 & {\left[I-V(I-A)^{-1} C(I-H)^{-1} Y\right]^{-1}} & 0 \\ 0 & 0 & {\left[I-(I-H)^{-1} Y V(I-A)^{-1} C\right]^{-1}}\end{array}\right][4]$

Where :

$\mathrm{S}=$ matrix of SAM direct coefficients

$\mathrm{A}=$ matrix of technical coefficients

$\mathrm{V}=$ matrix of value added (VA) coefficients

$\mathrm{Y}=$ matrix of VA distribution coefficients

$\mathrm{C}=$ matrix of expenditure coefficients

$\mathrm{H}=$ matrix of institutional and household distribution coefficients

After we calculate the $M_{1}, M_{2}$ and $M_{3}$ then we denote Stone's three submultipliers as $N_{1}, N_{2}, N_{3}$, they are :

1. Own or intragroup effects : $N_{1}=M_{1}$

2. Extragroups effects ( off diagonal matrix) : $N_{2}=M_{2} M_{3} M_{1}-M_{3} M_{1}$

3. Closed loop or intergroup effects (diagonal) : $N_{3}=M_{3} M_{1}-M_{1}$

We used multiplier $M_{a}$ to calculate the overall economy impact from policy implementation in this study. Then the overall impact will be decomposition into three submultipliers like Stone multiplier.

\section{IV.RESULT}

\section{A. Economic Impact From Increasing Output In} Transportation Sector

Implementation for every policy will have an impact to economy. In this study we estimate the impact of fiscal policy implementation that will increase output in transportation sector to every agents in economy.

Scenario that conducted in this paper is what if the deficit in balance of payment for transportation services in 2013 about 8,9 millions USD served by local company.

Economic impact from this scenario analyzed using Social Accounting Matrix multiplier. We can see the impact for every agents in economy which are production factors, institutions and production activities.

We can see the economy impact on the increasing of activity in transportation services sector in table 2 . 
TABLE II

ECONOMY IMPACT ON THE INCREASE OF OUTPUT IN TRANSPORTATION SERVICES

\begin{tabular}{lcc}
\hline \multicolumn{1}{c}{ Classification } & Impact (Billion IDR) & Impact (\%) \\
\hline Production Factors & 165.0 & $0.32 \%$ \\
Institutions & 197.6 & $0.28 \%$ \\
Production Activities & 634.3 & $0.26 \%$ \\
\hline \multicolumn{1}{c}{ Total } & 996.9 & $0.27 \%$ \\
\hline Source
\end{tabular}

Source : Author's calculation

In table 2 we can see that increasing activity in transportation services about 89 billion IDR can positively impact the overall economy about 996,9 billion IDR or about 0,27 percent from baseline. From the result we can see the impact for every agents in economy, for production factors about 165 billion IDR or about 0,32 percent from baseline for institutions about 197,6 billion IDR or about 0,28 percent from baseline and for production activities about 634,3 billion IDR or about 0,26 percent from baseline.

Economy impact for every agents in economy can be divided into each classification, we can see it in next table.

TABLE III

ECONOMY IMPACT FOR EACH CLASSIFICATION

\begin{tabular}{|c|c|c|c|}
\hline \multicolumn{3}{|c|}{ Classification } & $\begin{array}{c}\text { Changes } \\
(\%)\end{array}$ \\
\hline \multirow{5}{*}{ 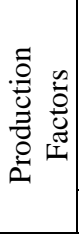 } & \multirow{4}{*}{ Labour } & Agriculture & $0.29 \%$ \\
\hline & & $\begin{array}{l}\text { Non-agriculture } \\
\text { unskilled }\end{array}$ & $0.38 \%$ \\
\hline & & Clerical and services & $0.47 \%$ \\
\hline & & Professional workers & $0.34 \%$ \\
\hline & Non-labour & & $0.25 \%$ \\
\hline \multirow{4}{*}{.气气 } & \multirow{4}{*}{$\begin{array}{l}\text { Household } \\
\text { Company } \\
\text { Government }\end{array}$} & Agriculture & $0.29 \%$ \\
\hline & & Non-Agriculture & $0.35 \%$ \\
\hline & & & $0.24 \%$ \\
\hline & & & $0.17 \%$ \\
\hline \multirow{5}{*}{ 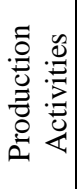 } & \multirow{2}{*}{\multicolumn{2}{|c|}{$\begin{array}{l}\text { Sector } \\
\text { Trade Margins }\end{array}$}} & $0.30 \%$ \\
\hline & & & $0.22 \%$ \\
\hline & \multicolumn{2}{|l|}{ Transport Margins } & $0.20 \%$ \\
\hline & \multicolumn{2}{|l|}{ Domestic Comodity } & $0.22 \%$ \\
\hline & \multicolumn{2}{|l|}{ Import Comodity } & $0.23 \%$ \\
\hline
\end{tabular}

Source : Author's calculation

We can see in table 3 the biggest economy impact in production factors occurs in labour classification for clerical and services about 0,47 percent, because according to the scenario, shock was given in transportation services sector. The second biggest impact occurs in non-agriculture unskilled about 0,38 percent, because this production factor closely related to transportation services sector.

Institutions classification that have the biggest impact is household in non-agriculture, its increase about 0.35 percent. The impact for company only about 0,24 percent, it means that income earning in transportation services are mostly for household institutions.

Classification for sector in production activities have the biggest impact about 0,3 percent, because the shock we put into sector classification not comodity classification. The impact for other classification in production activities about 0,20 until 0,23 percent.

The overall economy impact can be divided in three submultiplier stage which are intragroup, extragroup and intergroup effects. The intragroup effects matrix contains are the own, intragroup or direct effects multiplier. The intragroup effects from this study can be seen in the table below.

TABLE IV

ECONOMY IMPACT FROM INTRAGROUP EFFECTS

\begin{tabular}{ccc}
\hline Classification & Impact (Billion IDR) & Impact (\%) \\
\hline Production Factors & 0.0 & \\
Institutions & 0.0 & \\
Production Activities & 215.4 & $0.19 \%$ \\
\hline \multicolumn{1}{c}{ Total } & $\mathbf{2 1 5 . 4}$ & \\
\hline
\end{tabular}

Source : Author's calculation

Intragroup effects in this simulation we can see it in table 3 about 215,4 billion IDR or about 0,19 percent from baseline. It means that if we give a shock for transportation services 89 billion IDR, it can affect sectors in the production activities block for about 0,19 percent.

The extragroup effect is when a sector is affected by an external shock, then these multiplier show those effects that transmitted to other block. The extragroup effect for this simulation can be seen in next table.

TABLE V ECONOMY IMPACT FROM EXTRAGROUP EFFECT

\begin{tabular}{lcc}
\hline \multicolumn{1}{c}{ Classification } & Impact (Billion IDR) & Impact (\%) \\
\hline Production Factors & 165.0 & $0.32 \%$ \\
Institutions & 197.6 & $0.33 \%$ \\
Production Activities & 0.0 & \\
\hline \multicolumn{1}{c}{ Total } & $\mathbf{3 6 2 . 6}$ & \\
\hline
\end{tabular}

Source : Author's calculation

Extragroup effect in table 5 from shock in block production activities affect production factors about 165 billion IDR or 0,32 percent, while impact for institutions about 197,6 billion IDR or 0,33 percent. Overall extragroup effect from simulation about 362,6 billion IDR.

The third impact stage is intergroup effect, that represent effects that proceed outwards from the block where they originate and then feed back to it. The intergroup effects can be seen from next table.

TABLE VI

ECONOMY IMPACT FROM INTERGROUP EFFECT

\begin{tabular}{ccc}
\hline \multicolumn{1}{c}{ Classification } & Impact (Billion IDR) & Impact (\%) \\
\hline Production Factors & 0.0 & \\
Institutions & 0.0 & \\
Production Activities & 418.8 & $0.37 \%$ \\
\hline \multicolumn{1}{c}{ Total } & $\mathbf{4 1 8 . 8}$ & \\
\hline
\end{tabular}

Source : Author's calculation

From table 6 we can see that intergroup effect that gives impact to production activites back again after gives impact to production factors and institutions is about 418,8 billion IDR or 0,37 percent from baseline. The multiplier effect is bigger than the two multiplier effects earlier, because both production factors and institutions block impact the production activities block. The multiplier effect almost two times than intragroup effect.

\section{B. Equality in Infrastructure}

One of the Important factor to support the National Logistics System is adequate infrastructure all over the 
nation. The connectivity to distribute agriculture product can be easily made if there is an adequate infrastructure in every province in Indonesia.

If we compare construction value data by Province from BPSM, we can see there is a gap between infrastructure in each province in Indonesia. The construction value by province shown in next figure.

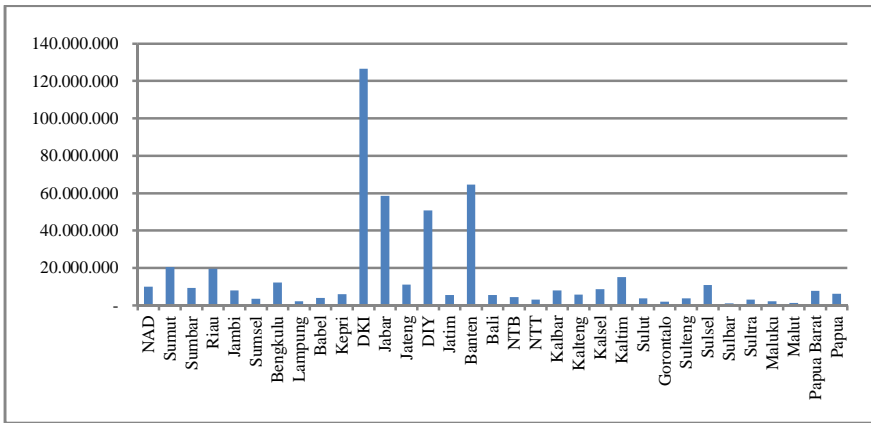

Fig. 4 Construction Value By Provinces in 2013

Source : BPS, Author's calculation.

We can see from figure 4 each province have different level of infrastructure value. There are four provinceS that have larger portion than other provinces, total percentage for that four province about 60 percent. Four provinces that have larger portion which are DKI Jakarta, Banten, Jabar and DIY.

Then construction value we divide it into each region, Sumatera, Java, Bali \& Nusa Tenggara, Kalimantan, Sulawesi and Papua \& Maluku. If we compare infrastructure value in Java region with other provinces, there is a large amount differences between them. We can see construction value from 2010 to 2013 by region in next figure.

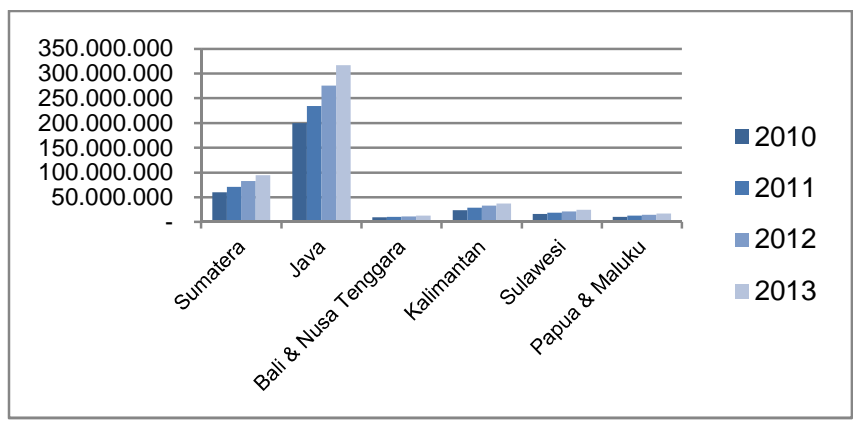

Fig. 5 Construction Value By Region From 2010 to 2013

Source : BPS, Author's calculation

In figure 5 we can see that construction value in Java region have the the biggest share from other region. And the second biggest share is Sumatera region. The portion for Java region is more than $60 \%$ from entirely construction value. Beside that, the growth from 2010 until 2013 also significant, from about 200 billion IDR in 2010, increase to over 300 billion in 2013 .

We can see there is a gap in construction value for every region in Indonesia, Java region have bigger portion than other region. If we want to establish connectivity all over Indonesia, than we should provide adequate and equal infrastructure for all provinces in Indonesia.
In graph 2 we can see that construction value in Java region have the the biggest share from other region. And the second biggest share is Sumatera region. The portion for Java region is more than 60 percent from entirely construction value. Beside that, the growth from 2010 until 2013 also significant, from about 200 billion IDR in 2010 , increase to over 300 billion in 2013.

We can see there is a gap in construction value for every region in Indonesia, Java region have bigger portion than other region. If we want to establish connectivity all over Indonesia, than we should provide adequate and equal infrastructure for all provinces in Indonesia.

According to reference [20] one of the main paradigm in MP3EI is 'Expansion' that refers to the integration of markets and production in Indonesia, right now its still fragmented Indonesia due to low connectivity on inter-corridor, intracorridor and the corridor to the international economy. Equitable distribution of infrastructure in MP3EI program focused on expanding the area that includes the construction of infrastructure that connects sentra- production centers in Indonesia.

Reference [21] mention that according to Deputy of Infrastructure in Bappenas, Dr. Dedi S. Priatna, there are several criteria for infrastructure development to get the reserve fund in RKP and the 2015 indicative ceiling, first is, strategic national infrastructure as well as areas that contribute to the improvement of connectivity, reduction in travel time, and reduction in cost of logistics including road trans-island, ports and airports; second isinfrastructure that increasethe accessibility in border areas and remote areas, including the border, the ring road in island, and pioneering shipping; Third is the basic infrastructure to improve people's access to clean water and securing economic center and community activities of the threat of flooding; and fourth, the infrastructure to support the efforts to fulfillmeet food security objectives through accelerating the construction of dams

One of main agenda in state budget 2014 is to increase spending for infrastructure to support domestic connectivity. If government can realize that agenda, and along with that domestic transportation services company increase, then it can support the establishment of National Logistic System in Indonesia

\section{Fiscal Incentives For Domestic Transportation Services.}

Fiscal incentives that goverment gives to reduce deficit in current balance budget in 2013 was additional deduction tax for labor intensive sectors. Through Finance Minister Regulation No. 124/PMK.011/2013 about The Amount of Reduction of Income Tax Article 29 in 2013 for Taxpayers in Specific Industries, additional deduction tax has been given to taxpayers in labor intensive sectors to increase domestic product and export, at the end it is expected that deficit in current balance budget can be reduced.

Recommendation to increase interest of investors in domestic transportation services is to give fiscal incentives. Domestic transportation services can be classified into labor intensive sectors, and it will reduce inequality between provinces in Indonesia. Therefore government should give incentives to attract interest from investors. Government should set requirements for the recipient of incentives to 
optimize the expected impact from that policy. Besides that goverment should give time limit for that industry until they can develop its own.

\section{CONCLUSIONS}

The increase of output in transportation services sector have positive impact to overall agent in Economy. The biggest impact in production factor is clerical and services labour, in institution the biggest impact occurs in non agricultural households. It means that the increasing activity in transportation services sector can increase welfare through increasing labour and household revenue in that sector.

If transportation services sector can grow equally throughout Indonesia, then the increasing on labor and household revenue can equitable distributed to all over the nation. At the end it be able to realize income distribution across the nation. Besides that government's strategies to create a National Logistic System can be realized.

Therefore government should support the increasing in transportation services sector particularly domestic transportation service. Firstly the government policy in infrastructure, can be more equitable, therefore no province that feel was treated unfairly in distribution of infrastructure budget. Secondly the government can give fiscal incentives like in Finance Minister Regulation No. 24/PMK.011/2013 about The Amount of Reduction of Income Tax Article 29 in 2013 for Taxpayers in Specific Industries, additional deduction tax has been given to taxpayers in labor intensive sectors.

To implement that fiscal incentives government should set requirements for the recipient of incentives to optimize the expected impact from that policy. Besides that goverment should give time limit for that industry until they can develop its own.

\section{REFERENCES}

[1] ANTARA. (2012)Kadin: Logistic Cost in Indonesia Most Expensive. [Online] Available : http://www.antaranews.com/berita/ 297289/kadin-biaya-logistik-di-indonesia-paling-mahal.

[2] Worldbank.(2014)Connecting to Compete Trade Logistics in the Global Economy: The Logistics Performance Index and Its Indicators. Washington DC: The International Bank for Reconstruction and Development.

[3] IMF.(1993)Balance of Payment Manual.

[4] Heakal, Reem.(2014)Exploring The Current Account In The Balance Of Payments. [Online]. Available :http://www.investopedia.com/ articles/03/061803.asp.

[5] Riley, Geoff.(2012) Balance of Payments - Deficits and Surpluses. [Online] Available: http://tutor2u.net/economics/revision-notes/a2macro-balance-of-payments-deficits.html.
[6] Pravakar Sahoo, et al."China's Growth Story: The Role of Physical and Social Infrastructure". Journal of Economic Development. March, 2012, Vol. 37.

[7] Browning, Jess."Development of Logistics and Transportation Systems in Promoting Trade \& Economic Growth: Comparing Incheon and Seattle Areas". Korea Observer. 2003, p. 589.

[8] Kim, S.C."Comprehensive Transportation and Storage Enforces National Competitiveness". Business Korea. May 1996, p. 40.

[9] Zhai, Fan."Benefits of Infrastructure Investment: an Empirical Analysis". Infrastructure for Asian Connectivity. Cheltenham, UK and Northampton, USA : Asian Development Bank Institute and Asian Development Bank, 2012.

[10] Bappenas.(2009) Developments Services And Indonesia's position in the GATS Negotiations Ahead. [Online] Available : http://www.bappenas.go.id/files/4013/5029/3012/9kajian_20090303 005257__.pdf.

[11] Sudarmo, Sudjanadi Tjipto."Back Empowering the Indonesian Port Management”. Jurnal Prakarsa Infrastruktur Indonesia. April, 2012.

[12] KP3EI.National Logistics System Blueprint, Locally Integrated, Globally Connected. [Online] Available : http://kp3ei.go.id/in/main_ind/content2/121/122.

[13] Bellamy, Vincent. HG.Org. The Implementation of Cabotage Principle in Indonesia. [Online] Available :http://www.hg.org/article.asp?id=19607.

[14] J.Defourny and E.Thorbecke. "Structural Path Analysis and Multiplier Decomposition within a Social Accounting Matrix Framework". The Economic Journal Vol.94, No.373, pp.111-136. Royal Economic Society. Wiley.1984

[15] A.A. Yusuf. "Constructing Indonesian Social Accounting Matrix for Distributional Analysis in the CGE Modelling Framework". Australian National University. Australia. 2006.

[16] BP. Resosudarmo, DA. Nurdianto and D. Hartono. Fundamentals of an SAM Analysis with an Aplication to the 2005 Indonesian InterRegional Social Accounting Matrix. [Online]. Available: http://www.csiro.au/Outcomes/Environment/Biodiversity/SocialAccounting-Matrix-basics.aspx.

[17] D. Holland and P. Wyeth. "SAM Multipliers: Their Composition, Interpretation and Relationship to Input Output Multipliers".Research Bulletin XB1027. Washington : Washington State University. 1993.

[18] G.Pyatt and J.I.Round. "Social Accounting Matrices for Development Planning. Social Accounting Matrices A Basis for Planning". A World Bank Symposium. Washington D.C. USA : The World Bank, 1985.

[19] R.Stone. "The Dissagregation of Household Sector in the National Accounts. Social Accounting Matrices for Development Planning. Social Accounting Matrices A Basis for Planning”. A World Bank Symposium. Washington D.C. USA : The World Bank, 1985.

[20] PKPPIM,FPA,MOF of Indonesia. Indonesian Initiative For Financing Infrastructure Investment in Global Cooperation. [Online]. Available

http://www.kemenkeu.go.id/sites/default/files/Inisiatif\%20Indonesia $\%$ 20Untuk\%20Pembiayaan\%20Investasi\%20Infrastruktur\%20Di\%2 0G20.pdf

[21] Bapenas. (2014). Strengthen National Connectivity, Government Continues To Build Infrastructure. [Online] Available: http://www.bappenas.go.id/berita-dan-siaran-pers/kuatkankonektivitas-nasional-pemerintah-terus-bangun-infrastruktur/ 